\title{
Analisis Evaluasi Kinerja Ride Sourcing Dengan Persepsi Pengguna
}

\author{
Analysis of Ride Sourcing Performance Evaluation with User Perception \\ N.H. Yunianti ${ }^{1 *}$, Abd. Rahim Nurdin ${ }^{1}$, Hijriah $^{1}$, Prilly Pricilia $^{1}$ \\ *Email: hadijah.yunianti@universitasbosowa.ac.id \\ ${ }^{1}$ Program Studi Teknik Sipil Fakultas Teknik Universitas Bosowa \\ Diterima: 17 September 2021 / Disetujui: 24 Desember 2021
}

\begin{abstract}
ABSTRAK
Transportasi sebagai komponen utama dalam mendukung kelangsungan kehidupan tidak bisa dilepaskan dari aktivitas keseharian manusia. Kedudukan transportasi sebagai penyokong kehidupan manusia mempunyai karakteristik yang berbeda-beda sehingga sangat bersifat spesifik, beberapa faktor yang mempengaruhi hal tersebut antara lain kondisi sosial demografis wilayah. Faktor-faktor tersebut memiliki pengaruh terhadap kinerja transportasi di wilayah tersebut. Tingkat kepadatan penduduk akan memiliki pengaruh signifikan terhadap kemampuan transportasi melayani kebutuhan masyarakat. Seiring dengan perkembangan transportasi, perkembangan teknologi dalam berbagai aspek kehidupan manusia juga semakin berkembang, dan salah satu pengaruh perkembangan teknologi informasi dalam dunia transportasi adalah munculnya platform yang mampu memenuhi kebutuhan sosial masyarakat terhadap transportasi umum, Hal ini tidak lepas dari ketersediaan internet yang luas memberi kita kemampuan untuk berdagang di mana saja dan telah membawa peluang besar di bidang transportasi dan perjalanan. Salah satu moda transportasi publik di Makassar yang saat ini mulai dikelola oleh pihak swasta yang dikenal dengan transportasi berbasis online (Ride Sourcing). Hal inilah yang menarik perhatian peneliti untuk melakukan penelitian terhadap penggunaan transportasi online tersebut dalam hal ini Grab Online dengan menganalisis kinerja transportasi online terhadap persepsi masyarakat dengan menggunakan metode deskriptif kualitatif. Pengolahan data dilakukan dengan metode persentase dan secara statistik dengan regresi linier berganda. Berdasarkan hasil pengolahan data maka diperoleh masing-masing koefisien efektivitas sebesar 0.472 dan koefisien efisiensi sebesar 0.479 yang dianalisa dari beberapa indikator yang paling berpengaruh dalam aspek efektivitas adalah indikator nyaman sebesar 0,485 dan indikator tarif / biaya sebesar 0,562 pada aspek efisiensi. Dimana secara keseluruhan, aspek efektivitas dan efisiensi memberikan pengaruh cukup kuat sebesar $71,3 \%$ terhadap persepsi masyarakat dalam penggunaan transportasi online (Grab).
\end{abstract}

Kata Kunci: Transportasi Online, Efektivitas, Efisiensi, Kenyamanan, Tarif

\section{ABSTRACT}

The Online Transportation Performance Analysis Of User Perceptions With A Statistical Approach. Transportation as a major component in supporting life cannot be separated from human daily activities. The position of transportation as a supporter of human life has different characteristics so very specifically, several factors that influence this include in the region's social demographic conditions. These factors have an influence on transportation performance in the region. The level of population density will have significance for the ability of transportation to meet the needs of the community. Along with the development of transportation, technological developments in various aspects of human life are also increasingly developing, and one of the developments in information technology in the world of transportation is the improvement of a platform that is able to meet the needs of the public for public transportation. One of the modes of public transportation in Makassar which is currently starting to be managed by private parties is known as online-based transportation. Grab Online by analyzing the performance of online transportation on people's perceptions using descriptive qualitative methods. Data processing is done by the method of contribution and statistics with multiple linear regression. Based on the results of data processing, obtained each acquisition 
coefficient of 0.472 and efficiency coefficient of 0.479 , which was analyzed from some of the most beneficial indicators in the aspect of competence in accordance with comfortable indicators of 0.485 and cost / cost indicators of 0.562 based on efficiency aspects. Where overall, the efficiency and efficiency aspects provide a quite strong amount of $71.3 \%$ to the public perception in the use of online transportation (GRAB)

Keywords: Performance, Effectiveness, Eficiency, Convenience, Rates

This work is licensed under Creative Commons Attribution License 4.0 CC-BY International license

\section{A. PENDAHULUAN}

Perkembangan kota akan terus meningkat seiring dengan tingginya jumlah penduduk. Dengan segala aktivitasnya, penduduk di perkotaan pun membutuhkan sejumlah ruang yang kemudian berimbas pada kebutuhan sarana transportasi dalam mobilitasnya antar ruang wilayah, baik ruang wilayah dalam kota maupun interaksinya dengan ruang-ruang wilayah.

Suatu sistem jaringan transportasi juga memiliki dua peran utama, yaitu sebagai alat pengendali arah pengembangan kota dan sebagai pergerakan manusia dan barang akibat adanya kegiatan di daerah perkotaan (Tamin, 2000).

Permasalahan yang tengah dihadapi kota-kota besar adalah kemacetan lalu lintas. Kemacetan muncul dipengaruhi oleh gaya hidup warga kota sendiri. Kota Makassar dengan luas wilayah administratif yang cukup besar $( \pm 175,77$ $\mathrm{km}^{2}$ ) untuk menjangkau seluruh sudut kawasan kota diperlukan sarana dan prasarana transportasi yang memadai.

Salah satu moda transportasi publik di Makassar yang saat ini mulai dikelola oleh pihak swasta yang dikenal dengan transportasi berbasis online, ojek online adalah sepeda motor taxi yang dapat dipesan melalui aplikasi seluler (Dielen, 2017). Beberapa keunggulan moda transportasi ini antara lain pengguna jasa cukup mudah mengaplikasi permintaan dalam melakukan perjalanannya, memiliki biaya yang relatif rendah dan pasti sesuai dengan yang tertera sebelum melakukan pemesanan, kondisi fisik dan pelaku tranportasinya cukup baik, aman dan nyaman karena menggunakan sistem lacak dan GPS, fitur yang telah tersedia pada perangkat ponsel pintar yang berbasis peta (Siuhi and Mwakalonge, 2016), lebih cepat dalam penjemputan dan pengantaran ke lokasi tujuan dan dapat dipesan kapan saja, bahkan kehadiran transportasi daring di Kota Semarang menyerap 2\% tenaga kerja yang sebelumnya tidak bekerja 
(Rakhmatulloh, Tyas and Subianto, 2019). Disisi lain moda transportasi ini justru mendapat hambatan oleh pihak pelaku moda transportasi publik lainnya. Hal ini membuktikan bahwa keberadaan transportasi berbasis online dapat menguasai pemasaran transportasi publik secara umum.

Maksud penelitian ini adalah untuk mengetahui sejauh mana persepsi masyarakat sebagai bentuk respon terhadap beroperasinya transportasi online (Grab) sebagai salah satu alat transportasi publik yang pada tahun 2017 mulai beroperasi. Sedangkan tujuannya adalah untuk menganalisis persepsi masyarakat pada transportasi online terhadap aspek efektivitas dan efisiensi.

Manfaat teoritis dari penelitian ini adalah munculnya suatu konsep teori transportasi publik perkotaan berbasis online, sebagai suatu jenis model transportasi baru yang berkembang sesuai dengan kebutuhan publik yang efektif dan efisien, dimana menurut (Mehmood et al., 2016) bahwa saat ini $40 \%$ perangkat cerdas yang digunakan dalam system transportasi. Sedangkan manfaat praktis yang dapat diperoleh adalah munculnya suatu kebijakan pendukung untuk mengarahkan dan mengatur sistem transportasi dalam hal opersionalnya dan bersinerginya antar moda transportasi publik perkotaan berbasis online, sebagai suatu jenis model transportasi baru yang berkembang sesuai dengan kebutuhan publik yang efektif dan efisien. Selain itu, adanya pemanfaatan teknologi sebagai dampak pengembangan teknologi.

\section{B. METODE PENELITIAN}

\section{Metode Penelitian}

Penelitian ini menggunakan metode penelitian deskriptif kualitatif (Satori Djam'an., 2010) mengungkapkan bahwa penelitian kualitatif dilakukan karena peneliti ingin mengeksplor fenomenafenomena yang tidak dapat dikuantifikasikan yang bersifat deskriptif seperti proses suatu langkah kerja, formula suatu resep, pengertianpengertian tentang suatu konsep yang beragam, karakteristik suatu barang dan jasa, gambar-gambar, gaya-gaya, tata cara suatu budaya, model fisik suatu artefak dan lain sebagainya.

Pada penelitian ini penentuan parameter efektivitas dan efisiensi dengan terlebih dahulu menilai kinerja ideal dari angkutan umum (K et al., 2012).

\section{Populasi dan Sampel}

Menurut (Sugiyono, 2012) populasi adalah wilayah generalisasi yang terdiri atas objek atau subjek yang mempunyai kualitas dan karakteristik tertentu yang 
ditetapkan oleh peneliti untuk dipelajari dan kemudian ditarik kesimpulannya. Berdasarkan lokasi penelitian di Kota Makassar, maka populasi merupakan penduduk Kota Makassar. terfokus di Kecamatan Makassar, dengan pertimbangan merupakan wilayah pusat kota dan pemerintahan.

Sampel adalah sebagian dari jumlah dan karakteristik yang dimiliki oleh populasi dijelaskan dalam buku Metode Penelitian oleh (Sugiyono, 2012) Cara dalam penentuan sampel, penulis menggunakan cara random sampling secara menyebar diwilayah penelitian yaitu masyarakat yang sering menggunakan jasa transportasi online dengan jumlah 100 sampel.

\section{Metode Analisis Pembahasan Penelitian}

Metode pembahasan yang digunakan adalah metode persentase. Metode ini akan didukung dengan hasil dari program SPSS (Statistical Package fot the Social Sciences) for windows versi 21 (Uji Regresi Linear) untuk memperoleh hasil analisa yang lebih maksimal pada penelitian ini.

\section{HASIL DAN PEMBAHASAN \\ 1. Variable Efektifitas dan Efisiensi \\ Hasil penelitian akan disajikan dalam dua kategori yaitu kategori variable}

efektivitas dan variable efisiensi, setiap variabel akan memberikan hasil yang kemudian akan menjadi kesimpulan dari masing-masing variabel tersebut. Diharapkan bahwa hasil yang diperoleh dapat memberikan kesimpulan bahwa adanya aplikasi online dapat meningkatkan efektivitas dan efisiensi (Siuhi and Mwakalonge, 2016)

Tabel 1. Persepsi Masyarakat terhadap Indidkator dalam Variabel Efektivitas

\begin{tabular}{|c|c|c|c|c|}
\hline \multirow[b]{2}{*}{ No. } & \multirow[b]{2}{*}{ Indikator } & \multicolumn{3}{|c|}{ Jawaban Responden (\%) } \\
\hline & & Setuju & $\begin{array}{l}\text { Ragu- } \\
\text { Ragu }\end{array}$ & $\begin{array}{l}\text { Tidak } \\
\text { Setuju }\end{array}$ \\
\hline 1 & Aksesibilitas & 94 & 4 & 2 \\
\hline 2 & Kapasitas & 83 & 15 & 3 \\
\hline 3 & Lancar dan Cepat & 88 & 12 & 1 \\
\hline 4 & Kemudahan & 93 & 7 & 1 \\
\hline 5 & Nyaman & 88 & 12 & 1 \\
\hline 6 & Aman & 76 & 23 & 2 \\
\hline & Rata-rata & 87 & 12 & 1 \\
\hline
\end{tabular}

Berdasarkan Tabel 1. dapat dilihat bahwa jawaban responden terhadap indikator pada variabel efektivitas menunjukkan rata-rata 87 sampel dari 100 sampel atau kurang lebih $87 \%$ pengguna jasa grab online mempersepsikan bahwa indikator efektivitas cukup tinggi yang diartikan bahwa dengan parameter yang sama secara normal jauh lebih baik kinerja pada grab online, dengan karakteristik aksesibilitas yang memiliki pengaruh paling besar dalam aspek efektivitas berdasarkan persepsi masyarakat. 


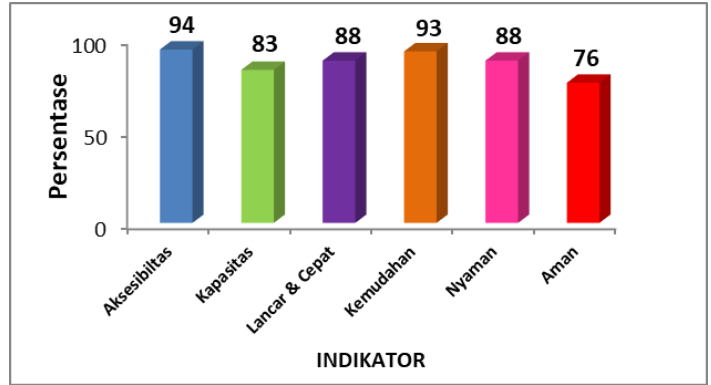

Gambar 1. Nilai Persentase Persepsi

Masyarakat Pengguna Transportasi Online

(Grab) Terhadap Variabel Efektivitas Per Indikator

Tabel 2. Persepsi Masyarakat terhadap Indidkator dalam Variabel Efisien

\begin{tabular}{lllll}
\hline \multirow{2}{*}{ No. } & Indikator & \multicolumn{3}{c}{ Jawaban Responden $(\%)$} \\
\cline { 3 - 5 } & Setuju & $\begin{array}{c}\text { Ragu- } \\
\text { Ragu }\end{array}$ & $\begin{array}{c}\text { Tidak } \\
\text { Setuju }\end{array}$ \\
\hline 1 & Tarif/Biaya & 82 & 16 & 3 \\
2 & Ketepatan & 85 & 14 & 1 \\
Rata-rata & 83 & 15 & 2 \\
\hline \multicolumn{2}{l}{ Sumber $:$ Hasil Analisa, 2021}
\end{tabular}

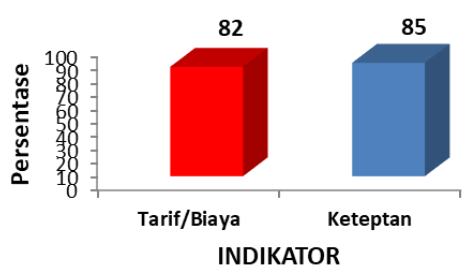

Gambar 2. Nilai persentase persepsi masyarakat pengguna transportasi online

(Grab) terhadap variabel efisiensi per indikator

Tabel 3. Uji Lineritas

\begin{tabular}{lllll}
\hline ANOVA & $\begin{array}{l}\text { Jumlah } \\
\text { Kuadrat }\end{array}$ & $\begin{array}{l}\text { Rata-rata } \\
\text { Kuadrat }\end{array}$ & F & $\begin{array}{l}\text { Nilai } \\
\text { Signifikar }\end{array}$ \\
\hline Regresi & 14.651 & 7.326 & 120.25 & $.000 \mathrm{~b}$ \\
& & & 9 & \\
Residu / Sisa & 5.909 & .061 & & \\
Total & 20.560 & & & \\
$\begin{array}{l}\text { a. Variabel Terikat : Y } \\
\text { b. Variabel Bebas: X2, X1 }\end{array}$ & & & \\
\hline
\end{tabular}

Berdasarkan Tabel 3, tersebut dapat dilihat bahwa nilai signifikan dari tabel ANOVA sebesar 0,000., kurang dari nilai signifikan $0,05(0,000<0,05)$, yang artinya adalah hubungan variabel $\mathrm{Y}$ dan semua variabel $\mathrm{X}$ bersifat linear. Berdasarkan hasil uji linearitas dapat disimpulkan bahwa aspek efektivitas dan efisiensi berpengaruh terhadap transportasi online (grab)

Tabel 4. Uji Korelasi

\begin{tabular}{|c|c|c|c|c|}
\hline Korelasi & & $\mathrm{X} 1$ & $\mathrm{X} 2$ & $\bar{Y}$ \\
\hline \multirow{4}{*}{$\mathrm{X} 1$} & Korelas & 1 & $.395 * *$ & $.688 * *$ \\
\hline & Pearson & & & \\
\hline & Nilai Siginifikan & & .000 & .000 \\
\hline & $\mathrm{N}$ & 100 & 100 & 100 \\
\hline \multirow{4}{*}{$\mathrm{X} 2$} & Korelas & $.395^{* *} *$ & 1 & $.721 * *$ \\
\hline & Pearson & & & \\
\hline & Nilai Siginifikan & .000 & & .000 \\
\hline & $\mathrm{N}$ & 100 & 100 & 100 \\
\hline \multirow{4}{*}{ Y } & Korelas & $.688 * *$ & $.721 * *$ & 1 \\
\hline & Pearson & & & \\
\hline & Nilai Siginifikan & .000 & .000 & \\
\hline & $\mathrm{N}$ & 100 & 100 & 100 \\
\hline
\end{tabular}

Dapat dilihat pada tabel diatas bahwa variabel bebas X1 dan X2 mempunyai korelasi 0,395 . Hal ini berarti variabel bebas $\mathrm{X} 1$ mempunyai korelasi yang cukup rendah dengan variabel X2 $(<0,5)$ sehingga tidak ada variabel yang dapat dihilangkan atau dapat dinyatakan bahwa variabel X1 dan X2 dapat digunakan. Begitu pula dengan variabel y yang memiliki nilai korelasi $>0,5$ terhadap variabel $\mathrm{x} 1$ dan $\mathrm{x} 2$ yang dapat disimpulkan bahwa variabel y menunjukan korelasi yang cukup kuat terhadap variabel $\mathrm{x} 1$ dan $\mathrm{x} 2$. Demikian juga dengan hasil dari nilai signifikan $<0,05$ yang menunjukkan bahwa variabel y dan variabel $\mathrm{x} 1$ dan $\mathrm{x} 2$ mempunyai korelasi.

Berdasarkan hasil uji korelasi dapat disimpulkan bahwa baik aspek efektivitas maupun aspek efisiensi tidak dapat dipisahkan atau memiliki hubungan yang erat, dimana keduanya memberi pengaruh 
yang cukup kuat terhadap pengaruh transportasi online (Grab).

Tabel 4. Uji Koefisien Determinasi ( $R$ Square/R2)

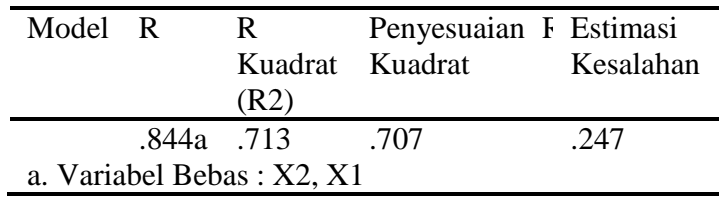

Dari hasil output SPSS tersebut, maka dapat dilihat bahwa nilai koefisien determinasi atau $\mathrm{R}$ square sebesar 0,713 atau $71,3 \%$. Hal ini menunjukkan bahwa variabel yang diteliti memberikan pengaruh terhadap loyalitas sebesar 71,3\% sedangkan sisanya dipengaruhi variabel yang tidak diteliti. Berdasarkan hasil uji koefisien determinasi (R Square) dapat disimpulkan bahwa aspek efektif (variabel bebas) dan aspek efisiensi (variabel bebas) berpengaruh cukup kuat terhadap pengaruh transportasi online Grab (variabel terikat).

Tabel 4. Pengujian Multikolinieritas

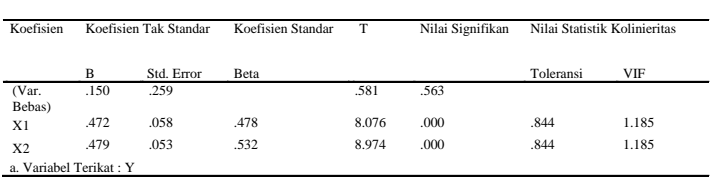

Berdasarkan hasil pengujian diatas, baik nilai tolerance 0,844 maupun VIF 1,185 antar variabel X1 dan X2 memenuhi nilai persyaratan sehingga dapat disimpulkan bahwa tidak terjadi multikolinearitas.

Dari pengujian diatas didapatkan model regresi sebagai berikut:
$\mathrm{Y}=0,150+0,472 \cdot \mathrm{X} 1+0,479 \cdot \mathrm{X} 2(\mathrm{R} 2=0,713)$

\section{KESIMPULAN DAN SARAN}

Hasil penelitian dan pembahasan dapat ditarik kesimpulan bahwa penggunaan aplikasi dapat menyediakan manfaat penting baik secara individu maupun kolektif terutama didalam mengurangi waktu dan biaya perjalanan, mengurangi kemacetan lalu lintas dan emisi kendaraan

\section{DAFTAR PUSTAKA}

Dielen, C. (2017) Unravelling Online Ojek's User Profile in Jabodetabek. Jamal, S., Habib, M. A. and Khan, N. A. (2017) 'Does the Use of Smartphone Influence Travel Outcome? An Investigation on the Determinants of the Impact of Smartphone Use on Vehicle Kilometres Travelled', Transportation Research Procedia. Elsevier B.V., 25, pp. 2690-2704. doi: 10.1016/j.trpro.2017.05.201.

K, M. A. et al. (2012) 'Evaluasi Efektivitas Dan Efisiensi Angkutan Umum Di Kawasan Tembalang', pp. 1-15.

Mehmood, Y. et al. (2016) 'M2M Potentials in logistics and transportation industry', Logistics Research, 9(1), pp. 1-11. doi: 10.1007/s12159-016-0142-y.

Rakhmatulloh, A. R., Tyas, W. P. and Subianto, M. H. (2019) 'Dampak Transportasi Berbasis Aplikasi Terhadap Penyerapan Tenaga Kerja Di Kota Semarang', Jurnal Pembangunan Wilayah \& Kota, 14(4), p. 253 . doi: 10.14710/pwk.v14i4.20663.

Satori Djam'an., K. A. (2010) Metode Penelitian Kualitatif. Bandung. 
Siuhi, S. and Mwakalonge, J. (2016) 'Opportunities and challenges of smart mobile applications in transportation', Journal of Traffic and Transportation Engineering (English Edition). Elsevier Ltd, 3(6), pp. 582-592. doi: 10.1016/j.jtte.2016.11.001.

Stalmašeková, N. et al. (2017) 'The Impact of Using the Digital Environment in Transport', Procedia Engineering. The Author(s), 192, pp. 231-236. doi: 10.1016/j.proeng.2017.06.040.

Sugiyono (2012) Metode Penelitian Kuantitatif Kualitatif dan R\&D.

Tamin, O. Z. (2000) Perencanaan dan Permodelan Transportasi.

Tumuwe, R., Damis, M. and Mulianti, T. (2018) 'Pengguna Ojek Online Di Kalangan Mahasiswa Universitas Sam Ratulangi Manado', Jurnal Holistik, 0(0). Available at: https://ejournal.unsrat.ac.id/index.p $\mathrm{hp} /$ holistik/article/view/20562. 